\title{
13
}

\section{A pragmatic approach to a successful election: A personal reflection}

\author{
Alisi Daurewa
}

\section{Introduction}

Filled with relief, yet a little saddened with the realisation that this moment would not return, I thanked God for gifting Fiji with the grace of a peaceful general election, after eight years under an unelected government led by former military commander Rear Admiral Voreqe Bainimarama, who removed Laisenia Qarase's elected government for alleged corruption and racism in a coup in December 2006.

The night was Wednesday, 17 September 2014, Fiji's general election day.

According to the 2014 Electoral Decree's Part 3, 19 (p. 234), the President, acting in accordance with section 59 of the Constitution must issue a writ to the Electoral Commission in every election. This task was performed by the Chief Justice (Gates) who was acting as president on 4 August, in the absence of His Excellency Ratu Epeli Nailatikau, who was away overseas. On Monday morning, 22 September 2014, upon receipt of the Final National Results Tally from the Supervisor of Elections (SoE) in accordance with section 103 
of the Decree, the Fijian Electoral Commission (FEC) allocated the seats of parliament in accordance with 104 and 105 of the Decree and by llam announced the names of 50 candidates elected to parliament. At noon on that day the writ was returned by FEC to the President of the Republic of Fiji, conveying the decision of the Fijian electorate in accordance with 106 of the Decree. Bainimarama and his FijiFirst Party won 32 seats. They formed the government while the Social Democratic Liberal Party (SODELPA) and National Federation Party won 15 and three seats respectively. They subsequently formed the Opposition. Later that day, we witnessed Bainimarama sworn in as Prime Minister of Fiji by the President, Ratu Epeli Nailatikau.

\section{Appointment of the Electoral Commissioners}

The seven members of the FEC were appointed by the President on 9 January 2014 as required under the 2013 Constitution. Chen Bunn Young is the Chairman of the Electoral Commission. He is a lawyer by profession, who has been running his private law firm for the last 30 years. Father David Arms is a priest belonging to the Columban order in the Catholic Church. He is the only member of the Commission to have had some experience with elections, as a member of the former electoral commission. Professor Vijay Naidu is a development scholar in the School of Government, Development and International Affairs at the University of the South Pacific. Jenny Seeto is a senior partner for the international chartered accounting firm PricewaterhouseCoopers. Larry Thomas is a renowned playwright and filmmaker. James Sowane is a successful tour operator in the tourism industry. I am a practitioner and advocate for people-centred development.

At the time of our appointment, the 2014 Electoral Decree was still being drafted, a supervisor of elections had yet to be appointed, and most of the staff at the elections office were on temporary employment. What was reassuring though was the presence of technical consultants funded by Australia, New Zealand and the European Union, who had begun the preparatory work for elections with help from staff at the Fijian Elections Office (FEO) and the Office of the Attorney General. 
Initially we realised that we were going to have to take a hands-on approach and began at least with what was doable despite the absence of necessary frameworks and personnel mentioned above. Our first task was the appointment of senior and middle management staff and the members of the FEC participated as chairpersons of several interview panels. This was an ongoing commitment for an additional three months. At times it was onerous because we were still committed to our other work, but we persevered nevertheless because we saw our role as a national calling. I thought the government was wise to appoint seven commissioners because it comfortably accommodated for the quorum of four in cases when some of us were absent.

\section{The Supervisor of Elections}

With a similar constitutional process to the appointment of members of the FEC, Mohammed Saneem was appointed by the President of the Republic of Fiji on recommendation by the Constitutional Offices Commission, which prior to the general elections comprised the Prime Minister and the Attorney General, who was also the Minister for Justice and Minister for Elections. Saneem had been an employee of the Ministry of Justice as Acting Permanent Secretary. The Minister for Elections had told some of us that the SoE would be an independent expatriate so it came as a complete surprise when the minister told us of Saneem's appointment. However, being practical people we were prepared to work with Saneem because he was already performing some functions of the SoE and under the circumstances we did not have the luxury of time. For my part, I found Saneem to be readily accessible. Having said this, the issue of who decides on operational policies is unclear. Soon after its appointment, the FEC had begun discussion with some of the technical consultants on developing policies and operational guidelines. However, after the appointment of the SoE this was not given the priority it deserved. On its part, the FEC was limited from pursuing this further in the absence of its own technical consultant, for which it had made an unsuccessful request. The importance of policies with clear operational guidelines cannot be overemphasised. From a governance perspective, this is an area that needs urgent attention and I am hopeful the FEC will be given the institutional support needed to effectively address this issue. 


\section{The Electoral Decree and other related decrees}

Despite oral and written representation on the draft electoral decree, very little was accepted by the Solicitor General. We were pleased though with the inclusion of two submissions on other decrees: the Immunity Decree and the right to appeal against the police officer making the decision to revoke a meeting permit. This was at the end of March 2014, the same time as Mr Saneem's appointment as SoE. There were concerns raised as some members of the public feared that a new voting system, plus choosing a number as opposed to a name, would be confusing. I believed that the assumption that rural people were ignorant was an insult to their intelligence. When I observed pre-polling in the outer islands of the Lau group, I was impressed to find aged voters voting with ease and without any problems. I soon found out that figures were not foreign to them because of their early exposure as Christians to reading the Bible, where they were required to cite the numbers of chapters and verses daily from the book of Psalms. They also dealt with numerical digits on a daily basis through counting money, remembering and dialling mobile numbers and through other means.

\section{The roadmap to elections}

By February 2014, despite our concern with the delay of the Electoral Decree and the appointment of the SoE, we went ahead and created a roadmap for the general elections with emphasis on voter education. We also realised that the success of actualising the roadmap would have to be based on a pragmatic approach, an example of which was utilising the opportunity the government had begun for us in engaging international technical consultants to work at the FEO. Jerome Leyraud, the team leader for the consultants, further developed the roadmap until we were ready to meet with development partners. Leyraud was highly valuable because of his international and legal expertise with elections. Unfortunately, we were not able to retain him to serve the commission after his term expired in April because the Attorney General did not approve our request and instructed us to use 
the services of the Solicitor General. We did not feel bound to go to the Solicitor General for advice all the time as we wanted to maintain our freedom to obtain legal advice elsewhere to ensure our independence.

\section{Election partners}

One of the strategic decisions we made was to ensure that all presentations and dialogue with potential partners and donors were to be conducted at the FEO building, which at that point needed renovation. This was to enable them to experience first-hand the state of our work environment, which at that time needed urgent attention.

Our presentation of the roadmap on 12 March 2014 was met with overwhelming support from the development partners. The roadmap included our strategy for voter education based on three simple questions: 'What is voting?' 'Why Vote?' 'How to vote?' The voter education process was to be staggered in three stages over the six months that were left before the elections. By coincidence and fortunately for us, the Fiji Women's Rights Movement was already engaged in civic education at that time, addressing the 'What' and 'Why' of voting via media outlets. This meant that we only needed to work on the 'How to vote' aspect.

Thus began a series of consultations, which the SoE continued with after his appointment at the end of March 2014. The support of development partners was manifested in the 54 per cent external contribution to the total general elections budget of FJD\$39,284,637. According to FEC's 2014 Report (p. 8), the total expenditure for FEO as at 31 December 2014 was FJD\$27,763,815.

In addition to development partners, I thought our regular meetings with political parties, media organisations, NGOs (including those concerned with disability issues), the police and representatives of the transport industry were very helpful. This continued well after the appointment of the SoE because we were conscious of the need to be on track with groups we respected as primary partners because of the important role each played. After all, the success of the general elections was also going to be dependent on their collective support. 
The task for the FEC was to establish a relationship with the different groups in recognition of the important role each played in the general elections within a very short period of eight working months, for we were appointed in January and the general elections were in September. Our meeting schedule changed according to the need and circumstances and we stepped back while the SoE continued meeting with the different groups. However, the FEC continued to meet with the police for security updates and the transport sector for logistical purposes, to address the rural electorate not regularly serviced by public transport.

\section{Secretariat issues}

While each commissioner was tasked with a certain responsibility, overall, the work of the FEC was affected by inadequate secretariat support for the initial five months of our appointment. Part of my task was to ensure that our minutes, correspondence and decisions were registered and regularly updated. Thankfully, the inclusion of two additional staff before the elections helped reduce our burden. Our secretariat staff worked hard, usually under trying conditions, because we were ourselves under a lot of pressure and were thus often demanding. They were always on hand to help us even late at night and they were incredibly patient and tolerant with us. In addition, we did not have a separate budget, which meant that we had to seek financial outlays for the work we did, including our claims for sitting allowance which were being approved by the SoE whose work we had responsibility over. This was an institutional conflict of interest that we tried to deal with as best as we could.

\section{Polling observation}

The commissioners participated as observers in both pre-polling and the actual poll day, including the counting of votes. In doing so, we developed our own checklist, which was helpful because lessons learnt from the pre-poll were reported to the SoE for consideration for poll day processes. The commissioners covered all four divisions, 
travelling the rugged terrain of the Colo (hinterland) in both Viti Levu and Vanua Levu, the coastal areas, and the unpredictable waters of the Lau and Beqa islands.

\section{Lau Province pre-poll}

I travelled to Lau in the Eastern Division, where the electorate voted by pre-poll. Lau is one of 14 provinces in Fiji and consists of several small islands. The islands are the farthest from the main island of Viti Levu and some of its islands, such as Ono-i-Lau, are nearer to the nearest Tongan island than to Suva. Amongst the provinces, Lau is considered the most challenged in terms of accessibility because its several small islands are scattered and because of the unpredictability of the weather.

Three groups of officials from the FEO administered the pre-poll in Lau, with each group travelling by ship, the cheaper and more practical option. I accompanied the third and biggest group in the government ship Iloilovatu, assigned to Northern Lau, which is made up of the islands of Oneata, Moce, Komo, Vanuavatu, Lakeba, Nayau, Cicia, Vanubalavu and all small surrounding islands - Tuvuca, Ogea, Katafaga, Susui, etc. We left Suva on Wednesday, 3 September 2014 after a delay of one day because of a mechanical problem with the ship. The third group consisted of 22 officials and 14 police officers. They were divided into seven teams. I accompanied the team as far as Cicia Island and returned by plane on Wednesday, 10 September.

While the FEO had already undertaken the task of ensuring protocols were observed and logistical arrangements made in their initial visit to the provinces before the elections, on arrival in the village, the chief and/or elders were presented with $i$ sevusevu (ceremonial offering of yaqona to the host, made in respect of recognition and acceptance of one another). From then on, the villagers took over the organisation and prepared food and bedding for the visitors. The Turaga ni Koro or village headman in each village played an important role in mobilising the villagers to vote. Aside from myself, the only other observers present were polling agents from SODELPA. I did not meet any polling agents from other political parties. 
The polling officials worked hard, often under trying conditions. Some who travelled in the Iloilovatu suffered from seasickness. For the team leaders, their dilemma was conforming to the voting schedule prepared by the FEO. This was difficult to follow because on sea, the ship's captain dictated which island to berth at first in accordance with the weather pattern. At times, this meant conducting the pre-poll in more than one island in one day, as they did for Nayau and Cicia islands, where Nayau polling was during the day and Cicia polling was in the evening on 8 September 2014. The polling agents did not return to the ship until the early hours of the next morning. On shore, they were met with friendly people but the terrain for some was not friendly. In Nayau, a policeman smashed his expensive mobile phone when he fell down a cliff with the empty ballot box on the team's way to a village on the other side of the island. Miraculously, he recovered in an instant without any damage to himself or the ballot box.

The electorate in most parts of Northern Lau thought voting was easy. The turnout was about 78 per cent. From observation and discussions with the voters, a number of factors were identified as vital in making voting easy and these included the following: a majority of the polling stations were in village community halls, some in schools and one in a private residence; all were within easy walking distance; there was an easy flow of voters into and out of the polling station; the polling officials assisted where necessary, including helping those with disability issues and taking the poll to the sick and the weak at homes and in hospital beds; a boat carting voter instruction booklets arrived in Lau ahead of the polling teams; the booklets were distributed to the people before polling day. By the time the same booklets were given to the voters in the polling stations, most of them were familiar with the process. Some polling officials explained the process whilst handing out the polling paper. Voters who regularly read the Christian bible were not intimidated by numbers and this included the octogenarians, most of whom were women. In some villages there were question and answer sessions with the author after the sevusevu, whilst waiting for the polling officials to set up the polling stations. 
Table 1: Details of polling in five Lau islands

\begin{tabular}{|l|l|l|r|r|r|}
\hline Date & Island & Station & Voters List & No. Voted & \% Voted \\
\hline $4 / 9 / 14$ & Moce & Nasau & 286 & 221 & $77 \%$ \\
\hline $4 / 9 / 14$ & Komo & Komo & 112 & 86 & $77 \%$ \\
\hline $5 / 9 / 14$ & Lakeba & Tubou & 490 & 299 & $61 \%$ \\
\hline $6 / 9 / 14$ & Lakeba & Yadrana & 135 & 107 & $79 \%$ \\
\hline $6 / 9 / 14$ & Lakeba & Waciwaci & 154 & 103 & $67 \%$ \\
\hline $6 / 9 / 14$ & Lakeba & Vakano & 52 & 42 & $81 \%$ \\
\hline $8 / 9 / 14$ & Nayau & Salia & 87 & 68 & $78 \%$ \\
\hline $8 / 9 / 14$ & Cicia & Tarakua & 105 & 89 & $85 \%$ \\
\hline $8 / 9 / 14$ & Cicia & Naceva & 53 & 43 & $81 \%$ \\
\hline $8 / 9 / 14$ & Cicia & Lomati/Tabutoga & 119 & 106 & $89 \%$ \\
\hline $8 / 9 / 14$ & Cicia & Mabula & 297 & 248 & $84 \%$ \\
\hline Total & & & 1,890 & 1,412 & $78 \%$ \\
\hline
\end{tabular}

The table above includes only those polling stations I visited and those I was able to obtain data for from the respective presiding officers. At the Tubou polling station, the low turnout of 61 per cent was partly due to an administrative oversight. Twenty people who produced identification cards were not included in the voters' roll. Secondly, and a common concern shared by all the islanders, the pre-poll was unexpected. Despite radio announcements from the FEO advising the change in the method of voting, it appeared many of the islanders were caught by surprise. A majority still expected to vote on 17 September. Hence those who were elsewhere, like the Methodist Church ministers and their respective island delegations who were in Suva for their annual conference, joined the list of non-voters from Lau.

\section{International interest}

The FEC was hosted by the Australian and New Zealand Electoral Commissions in July and August 2014 respectively. These visits provided insight into their electoral systems and increased my appreciation of engaging non-government workers in the administration of elections, which Fiji has now adopted. When the Multinational Observer Group (MOG) arrived later in Fiji, it was good to meet with some of those we had met earlier in Australia and New Zealand. 


\section{Conclusion}

Overall, for the commissioners, the road to the elections was not an easy walk. There were disagreements between the FEC and SoE, as eventually evidenced in the court proceedings filed in the High Court to determine what the SoE was bound to do upon 'directions' given him by the FEC. But, much like a rough journey, we managed to negotiate our way through sharp pebbles and rocks under the able leadership of our chairman because each one of us was committed and determined to ensuring there was an election to give the Fijian people the opportunity to vote for their government.

In the end, as they say, the rest is history. Fiji went to the polls with 0.7 per cent of invalid votes. Out of a total 591,101 registered voters, 500,078 or 84.6 per cent actually voted.

To be able to pull this off within eight months, it had to be an election with a pragmatic approach plus a lot of faith. I was honoured to have served my country with the other six commissioners, who brought with them their unique professional skills, vast and diverse experiences and deep wisdom. As a team we didn't forget to laugh! The SoE and his team, including over 9,000 poll-day workers and the technical consultants, worked tirelessly. They showed that cooperation and commitment towards a common national purpose could overcome obstacles. I couldn't have asked for more.

\section{Disclaimer}

This is the personal opinion of the author and not of the Fijian Electoral Commission of which she is a member.

\section{References}

Government of Fiji 2014, Electoral Decree, Government Printers, Suva.

Fijian Electoral Commission 2014, Fijian Electoral Commission Report, Government Printers, Suva. 
Fijian Electoral Commission \& Supervisor of Elections 2014, 'Joint Report on General Election by the Fijian Electoral Commission and the Supervisor of Election to H.E. the President of the Republic of Fiji and the Secretary General to Parliament', Suva. 
This text is taken from The People Have Spoken: The 2014 Elections in Fiji, edited by Steven Ratuva and Stephanie Lawson, published 2016 by ANU Press, The Australian National University, Canberra, Australia. 